\title{
Pollen Deterioration in a Tropical Surface Soil and its Impact on Forensic Palynology
}

\author{
Wongkot Phuphumirat ${ }^{*, 1}$, Dallas C. Mildenhall ${ }^{2}$ and Choathip Purintavaragul ${ }^{3}$ \\ ${ }^{I}$ Forensic Science Program, Faculty of Science, Prince of Songkla University, Hat Yai, Songkhla, Thailand. 90112; \\ ${ }^{2}$ GNS Science, P.O. Box 30368, Lower Hutt, New Zealand; ${ }^{3}$ Department of Biology, Faculty of Science, Prince of \\ Songkla University, Hat Yai, Songkhla, Thailand, 90112
}

\begin{abstract}
Although pollen evidence can remain at a crime scene for many years, some pollen species are more susceptible to decay than others. Mature pollen grains of 9 pollen species were placed in nylon gauze bags and buried in 3 types of tropical soil, leaf mold, swamp clay, and sandy soil, in June 2007. Degradation rates and effects of some environmental factors on pollen deterioration were then determined. Observations were made after 2, 4, and 6 months of burial, and the pollen classified into 3 types: identifiable, non-identifiable to species, and absent in the case of complete destruction. Results showed that pollen from different plant species had different rates of deterioration but in all cases pollen deteriorated more slowly in sandy soil. Soil $\mathrm{Eh}$ and $\mathrm{pH}$, and infection by fungi seemed to have little influence on pollen preservation. However, pollen preservation of some pollen species was affected by time. It is apparent that complex destructive factors play different roles in different depositional settings. This allowed each area to yield a unique pollen composition. From a forensic point of view, this specific composition becomes part of the evidence that may link a suspect to the precise crime scene.
\end{abstract}

Keywords: Pollen deterioration, tropical soils, forensic palynology.

\section{INTRODUCTION}

Forensic palynology is a science focusing on modern and fossil pollen, spores, and other acid-resistant microscopic plant remains for legal purposes (by convention, spores are included in the term pollen). In forensic palynology, pollen preservation is an important factor that should be taken into account, the significance of which has been illustrated in many forensic cases. For example, in 1959, in one of the earliest reported cases, it was found that well-preserved pollen grains of a 20 million-year-old, Miocene-age fossil hickory were a key piece of evidence in the attempt to pinpoint where a victim had been killed and buried [1-3].

However, not every pollen species can be well preserved. Forensic palynologists may need to consider how much, and which type, of pollen may be lost due to the differential resistibility of each pollen species. Although for over five decades palynologists have been trying to understand the mechanisms behind pollen deterioration, the components determining pollen deterioration or preservation are still unclear $[3,4]$. Many investigators have pointed out that each pollen type preserves differently in different sediment types as a result of a combination of the properties of the pollen grains themselves and their depositional circumstances [511]. The chemical composition of pollen exine appears to be primarily an internal factor influencing the preservation potential of pollen, since it is composed of a durable

*Address correspondence to this author at the Forensic Science Program, Faculty of Science, Prince of Songkla University, Hat Yai, Songkhla, Thailand. 90112; E-mail: Pwongkot@hotmail.com compound sporopollenin. The lower the ratio of sporopollenin present in the total mass of the pollen wall, the lower the potential of that grain to be preserved in sediment. However, sporopollenin is very sensitive to oxidation. The morphology and ornamentation of pollen are also internal factors impacting on the resistance of pollen. Thin-walled pollen, bladders of many conifer species, or the spines of certain composites tend to be more susceptible to decay than others $[5,10,12-15]$.

A low soil Eh (redox potential) indicates a reducing situation where oxygen concentrations are low and hydrogen sulphide and carbon dioxide are often the by-products of soil microbe respiration. This combination reduces oxygen levels, restricts complete oxidation of organic substances, and decreases $\mathrm{pH}$ values of sediment. Such sediment also provides an unsuitable habitat for some types of fungi that can destroy pollen by their rhizoids or hyphae penetrating the pollen aperture to feed on the protoplasm [4, 16, 17]. Sediment with a low $\mathrm{Eh}$ and $\mathrm{pH}$ becomes ideal for the preservation of pollen $[9,10,18,19]$.

One factor clearly identified as a destructive agent is the repeated cycles of soil hydration-dehydration. The pollen walls can stretch to allow for expansion and contraction, depending on the humidity of the environment. This repeated changing of volume weakens pollen grains over time and destroys them. Many experiments have shown that after a few wet-dry cycles significant damage to pollen grains occurs $[4,11,17,20]$.

From a forensic point of view, the preservational state of pollen is a clue to whether pollen has come from a specific crime scene. Problems can occur when the preservational state of pollen at a crime scene deteriorates rapidly after the 
crime was committed and the pollen is different in its preservation characteristics or its composition from what was originally taken from the scene. This can happen when there is a long time interval between the crime and the collection of comparator samples. Therefore, a better understanding of pollen degradation in surface soil and its impact on forensic palynology is needed.

\section{MATERIALS AND METHODOLOGY}

\subsection{Study Sites and Methods}

Deterioration of pollen in surface soil was experimentally tested in three types of tropical soil: leaf mold, swamp clay, and sandy soil. A preliminary study of soil types within Songkhla province, Thailand, showed three separate sites representing the three types of soil selected as study sites: 1) leaf mold (N 0700'16.5”, E 100³0’28.2”), Kao Ko Hong, Prince of Songkla University, Hat Yai district, 2) swamp clay (N $07^{\circ} 00^{\prime} 30.1^{\prime \prime}$, E $\left.100^{\circ} 30^{\prime} 20.1^{\prime \prime}\right)$, the swamp within Prince of Songkla University, Hat Yai district, and 3) sandy soil (N 07¹0'43.8”, E 100³7’28.8'), at Kao Seng beach, Muang district (Fig. 1). The climate of these areas is under the influence of the monsoons. There are three dominant seasons, a rainy season dominated by the southwest monsoon (May to October), another wet season from November to December and a dry season both dominated by the northeast monsoon (November to April).

The experiment consisted of two parts, the first part was to determine the rate of pollen degradation. Pollen of nine flowering plants, Thunbergia erecta (Benth.) Anderson, Celosia argentea L., Zephyranthes candida (L.) Herb., Wedelia trilobata (L.) Hitch., Merremia umbellata (L.) Hall.f., Hibiscus rosa-sinensis L., Acacia auriculiformis A. Cunn. ex Benth., Musa sapientum L. and Nelumbo nucifera Gaertn, commonly found in this area, were examined. Their pollen morphologies have been described previously [2123]. All grains were collected from the fertile part of plants and kept at $-18{ }^{\circ} \mathrm{C}$ until used. Two hundred mature pollen grains from each plant were placed in nylon gauze bags (15 bags per plant taxon per site) with mesh openings of $16 \mu$ to allow fungi and bacteria to enter, but prevent escape of pollen. 405 bags were buried in the 3 types of soils at a depth of $1 \mathrm{~cm}$ in June 2007 for periods of 2, 4, and 6 months. Control pollen grains were examined before burial to monitor the preservation state of each pollen species. In June $2007,100 \%$ of the pollen grains were identifiable. At each sampling time, a total of 135 pollen bags were recovered, and the pollen grains were examined in the laboratory. Pollen grains in the bags were stained with $0.5 \%$ aqueous safranine for 5 minutes and washed with distilled water. All pollen grains were then removed from the bag using an autopipette and counted. The recovered pollen was examined using a compound light microscope and classified into 3 types: 1) identifiable to species, 2) non-identifiable to species, and 3) absent in the case of pollen grains not found because of complete destruction.

The second part was to study effects of some environmental factors, i.e. $\mathrm{pH}$, Eh, and fungal infection, on pollen deterioration. Soil properties, i.e. $\mathrm{pH}$ and $\mathrm{Eh}$, were determined according to standard methods [24]. All factors were measured at the same time when bags were recovered. Soil Eh and $\mathrm{pH}$ were measured using Orion combination $(\mathrm{Pt}$ and $\mathrm{Ag} / \mathrm{AgCl})$ electrodes and $\mathrm{pH}$ meter. Soil water extracts (1:5 soil:water) were used for $\mathrm{pH}$ analysis.

Fungal infection of pollen was tested in the laboratory using a pollen-baited culture method [16]. The top two $\mathrm{cm}$ of surface soil were collected from the 3 study sites in August, October, and December. In each site, five samples collected were homogenized and divided into $9 \times 10 \mathrm{cc}$ portions and a

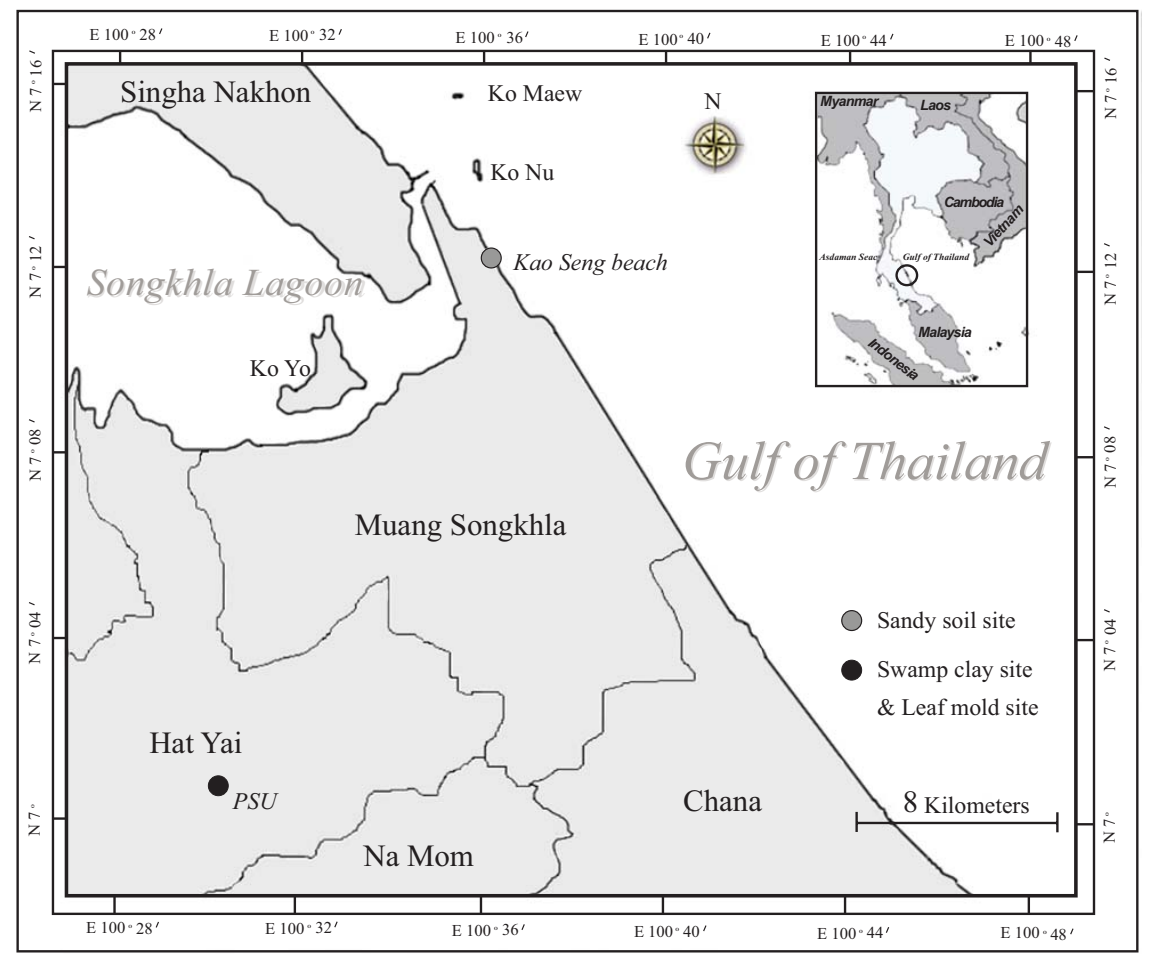

Fig. (1). Map of the study sites; leaf mold and swamp clay sites, Prince of Songkla University (PSU), Hat Yai district, and sandy soil site, Kao Seng beach, Muang district, Songkhla province, Southern Thailand. 
total of 27 cultures were prepared for 3 replicates. Pollenbaited trapping was examined daily for ten days. The percentage of infected pollen grains was calculated. A preliminary study showed that many kinds of soil microorganisms attacked the pollen grains. All pollen grains were infected by bacteria but only some of them were attacked by fungi. In this study, pollen grains attacked by bacteria were not counted as being invaded pollen.

\subsection{Statistical Analysis}

The relationships between pollen deterioration, time interval, and environmental factors, were then assessed using stepwise multiple regressions. The aim was not to develop predictive models, but rather to give information on types of factors that might be controlling preservation of each pollen species. All data was analyzed using the computer program SPSS version 10.0 .

\section{RESULTS}

\subsection{Pollen Deterioration}

In each soil type, the pollen species reacted differently over time as each species was influenced by different factors. However, in all cases the trend was for a loss of pollen. All pollen species placed in each sediment type rapidly deteriorated so that it only took 2 months for a very large number of pollen grains to disappear. Auto-oxidation had no effect on pollen preservation during sample preparation as there were no changes in preservation characteristics and quantity of pollen. Although, in this study, various states of pollen preservation were observed, each remaining pollen sample was counted and classified according to whether pollen could be identified as this indicated the forensic value of each species.

In swamp clay and leaf mold, pollen preservation was poor. There was clear evidence that more than $75 \%$ of Wedelia trilobata, Acacia auriculiformis, Hibiscus rosasinensis, and Merremia umbellata pollen were lost after 2 months of burial (Fig. 2a, 2b). Pollen of these four species deteriorated more slowly in sandy soil. Percentages of their identifiable pollen were $28 \% \pm 4.06,39.9 \% \pm 12.01,60.5 \%$ \pm 7.34 , and $30.8 \% \pm 7.59$, respectively, which were higher than those in swamp clay and leaf mold. After 4 months of deposition, virtually no pollen of Wedelia trilobata and Acacia auriculiformis could be identified (Fig. 2c).

Some pollen species seemed to behave similarly in all sediments. Pollen from Celosia argentea, Thunbergia erecta, and Zephyranthes candida tended to be similar in numbers at the same time of recovery even in different sediments. The more susceptible pollen species were Nelumbo nucifera and Musa sapientum with the lowest percentage of identifiable grains throughout the experiment; less than $8.3 \% \pm 4.07$ and $2 \% \pm 0.91$, respectively (Fig. 2a, 2b, 2c). Except for the Nelumbo nucifera bag $(45.6 \% \pm 6.49)$ percentages of nonidentifiable pollen recovered from all pollen bags were also low at less than $18 \%$ (Fig. 3a, 3b, 3c). The rest had presumably been completely degraded.

\subsection{Soil Properties}

The $\mathrm{pH}$ and Eh properties of each soil type are shown in Table 1. For sandy soil most values changed little. In leaf mold the only significant change was that Eh increased from
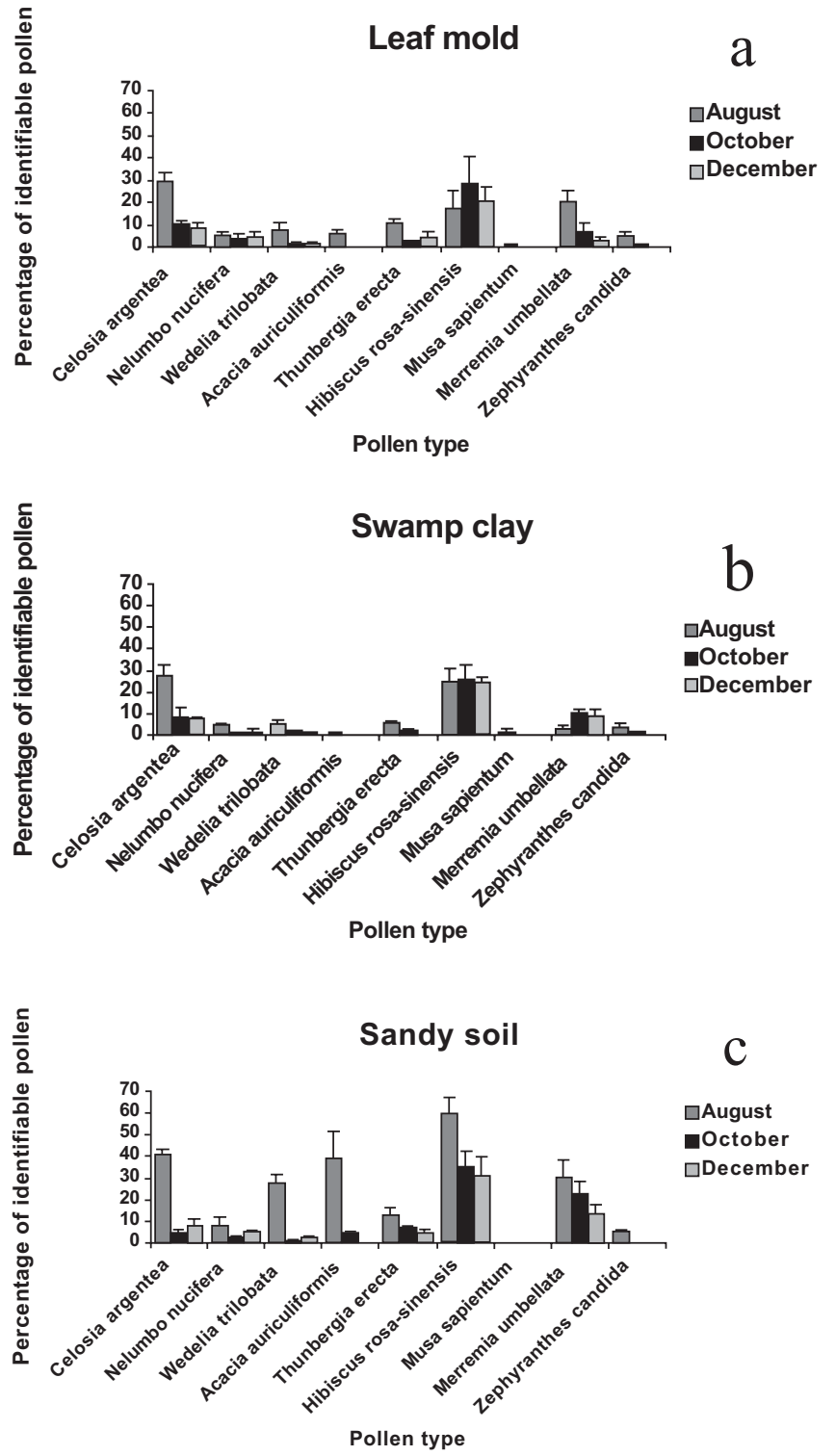

Fig. (2). Bimonthly changes of the percentage of identifiable pollen a-c: (a) buried in leaf mold; (b) buried in swamp clay; (c) buried in sandy soil. Data are the mean \pm SE of 5 replicates.

198.5 to 256.0 over the 6 month period, the highest value recorded, with no significant change in $\mathrm{pH}$, whereas with swamp soil Eh values reduced from 45.0 to 18.5 .

\subsection{Fungal Infection}

The trend in each experiment in the number of pollen attacked by fungi was similar. Pollen grains in the leaf mold tended to have most infections, followed by swamp clay and sandy soil, respectively. In leaf mold more than $55 \%$ of Wedelia trilobata, Acacia auriculiformis, Thunbergia erecta, Musa sapientum, Merremia umbellata, and Zephyranthes candida pollen were infected. In swamp clay Thunbergia erecta and Musa sapientum pollen also seemed to be most infected. Sandy soil did not appear to provide the best conditions for fungal infection, as the numbers of infected pollen were very low. Hibiscus rosa-sinensis pollen were least infected at less than $3 \%$ (Fig. 4) in all soil types. 

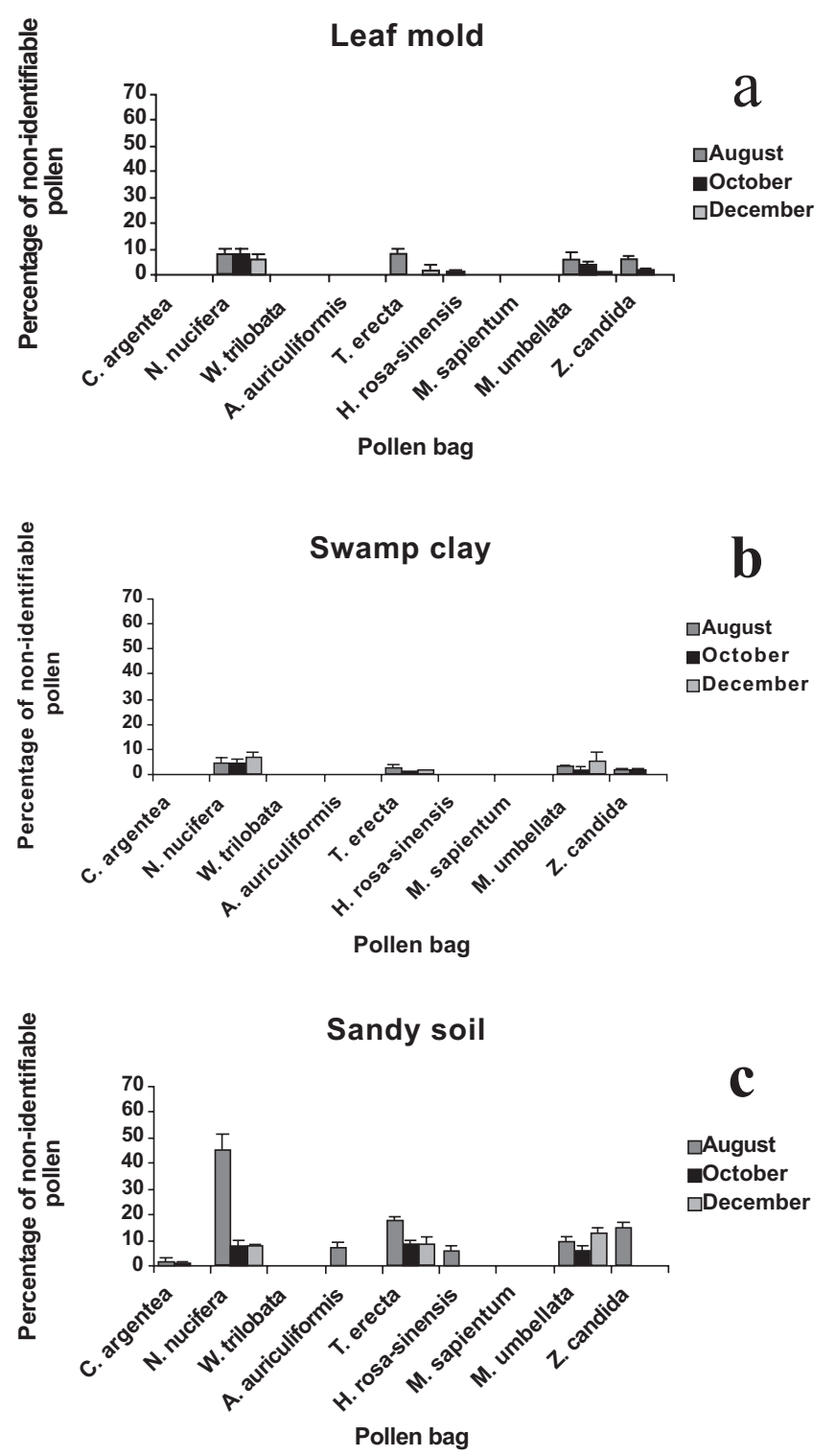

Fig. (3). Bimonthly changes of the percentage of non-identifiable pollen recovered from pollen bags of each pollen species a- c: (a) buried in leaf mold; (b) buried in swamp clay; (c) buried in sandy soil. Data are the mean \pm SE of 5 replicates. Full generic affiliations are given in Fig. (2).

\subsection{Effects of All Environmental Factors on Pollen Deterioration}

The pollen species were classified into three groups on the basis of the significant factors selected by regression analysis. Group 1 species - pollen whose deterioration appeared to depend on time, Celosia argentea, Thunbergia erecta, and Zephyranthes candida. Group 2 species - pollen whose degradation appeared to be influenced by soil $\mathrm{pH}$, Hibiscus rosa-sinensis (Table 2). Group 3 species - mainly susceptible pollen whose decomposition appeared to be controlled by factors other than time and $\mathrm{pH}$, Nelumbo nucifera, Wedelia trilobata, Acacia auriculiformis, Musa sapientum, and Merremia umbellata (data not shown in Table 2).

\section{DISCUSSION}

\subsection{Pollen Deterioration}

In this study rapid pollen deterioration occurred in all samples in all sediments. In most cases, more than half the pollen in each depositional environment was lost after only 2 months of burial. This result contrasts with a study by Havinga where more than 20 percent of pollen from many species were observed, even when pollen had been deposited in sediments for 20 years in a temperate region of the world [6]. Differences in pollen concentrations recovered from different climate zones were found by Dimbleby where lower concentrations of recovered pollen occurred in tropical soils relative to temperate soils in areas with a similar soil $\mathrm{pH}$ value [18]. The tropical zone provides the impetus for rapid pollen destruction since tropical ecosystems are characterized by high rates of energy flow with rapid decomposition and high potential for loss of soil organic matter [25]. The rate of organic decomposition in tropical environments is five times greater than that in temperate environments [26].

In this study pollen from different plant species deteriorated at different rates probably caused by differences in chemical composition and molecular structure within the exine of each species. These differences between each pollen species or even each grain made specific pollen types differentially susceptible to environmental stress $[4,5,10$, 27-30]. The most susceptible grains were Musa sapientum and Acacia auriculiformis pollen with very thin exines [21, 31-35].

Each pollen species react in their own way to different environments of deposition because pollen degradation is a combination of genetics and environmental conditions [7]. In this study pollen deterioration proceeded more slowly in alkaline sandy soil, especially Hibiscus rosa-sinensis pollen, even though alkaline environments are not ideal for the preservation of pollen $[8-9,18]$. The sandy beach site was drier than other sites and pollen preservation may have been controlled by salinity and repeated cycles of soil hydrationdehydration rather than $\mathrm{pH}$. Growing hydrated salt crystals may have enclosed pollen protecting them from stress associated with desiccation [11]. The low number of wet-dry cycles in dry sediment also provides ideal conditions for pollen preservation $[17,20,36]$.

Although swamp clay and leaf mold provided different soil conditions, nearly all pollen species reacted similarly in both sites. In swamps frequent wet-dry cycles influenced by water level fluctuations are a degrading factor, while in leaf mold pollen deterioration appeared to be affected by high biological activity $[6,12]$. That these different sites produced similar rates of deterioration suggests that agents of pollen degradation interact differently in different depositional settings [4]. After the first two months of severe destruction the few remaining pollen grains of Nelumbo nucifera and Wedelia trilobata would likely be resistant to further decay. These results support what has been found with other pollen groups such as Alnus and Corylus [6].

In our experiments, pollen preservation was not influenced by sediment Eh even though it is an important agent in the preservation of pollen [9-10, 19]. This might be because all soil Eh values were reducing conditions so pollen 
Table 1. pH and Eh Soil Properties of Each Soil Type Measured During the Experimental Period from August to December 2007

\begin{tabular}{|c|l|c|c|}
\hline \multirow{2}{*}{ Month } & \multicolumn{1}{|c|}{ Soil type } & pH & Eh \\
$(\mathbf{m V})$.
\end{tabular}

preservation was influenced evenly in all sediments [37, 38]. However, soil Eh values obtained are likely to be unrepresentative, especially in the swamp site, because of water level fluctuations during the experiment. Soil fungi were not a main causative factor in pollen degradation either. Pollen deterioration might also be effected by other soil microorganisms, such as soil bacteria, but this was not detected by the pollen-baited culture method. However, there may be other potentially destructive agents influencing pollen preservation.

Time is an important factor affecting pollen deterioration as shown by Celosia argentea, Thunbergia erecta, and Zephyranthes candida and also shown by Havinga who found similar pollen percentages of Betula, Salix, Populus, and Myrica left in leaf mold and river clay and recovered at the same time [6]. However, there is no clear reason to explain this behaviour of pollen and more research is needed. Note that correlations between degradation of Thunbergia erecta and Zephyranthes candida and time were calculated from a narrow range of identifiable pollen concentrations.

\subsection{Pollen Deterioration and Forensic Palynology}

Since each geographic area provides particular agents of pollen deterioration each pollen species will respond in its own way to these agents leading towards the establishment of a unique pollen composition at each site.

In the present study pollen decay was rapid. Similarly, all seasonal palynomorphs in a fertilized soil of a ploughed field can disappear within 4 months or possibly less [39]. This rapid degradation of pollen can be a problem when visualizing vegetation in the search for unknown crime scenes [40]. If pollen at a crime scene deteriorates rapidly, vegetation may not be represented by pollen removed from the scene.

Pollen at a crime scene may be different in its composition from that originally taken from the scene when there is a long time interval between the crime and the collection of comparator samples after the crime was committed. For example, if all 9 pollen species in this study were in the same area as the crime and comparator samples were collected more than 6 months later, in the worst case,
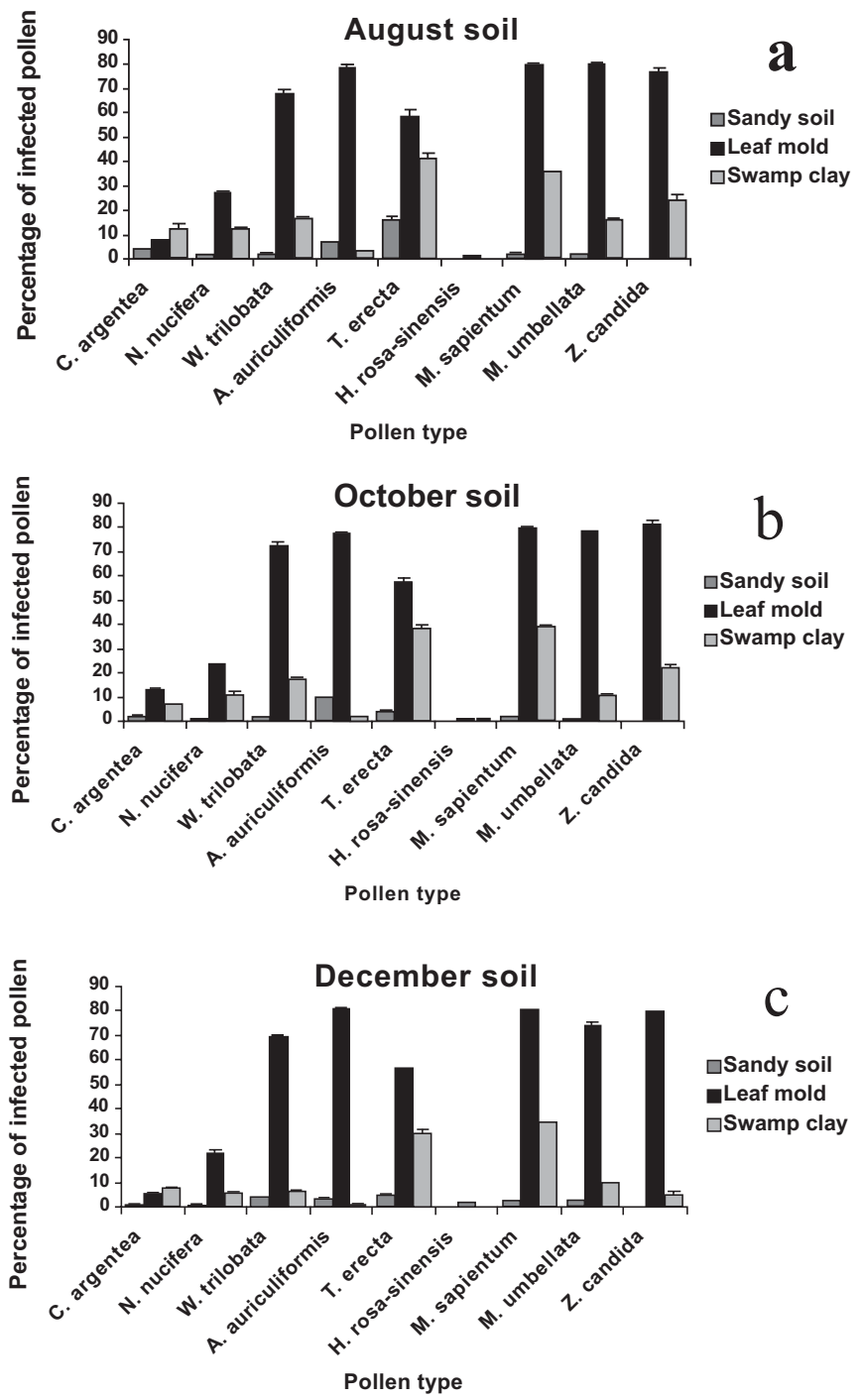

Fig. (4). The percentage of infected pollen of each pollen species in each soil type a - c: (a) August soil; (b) October soil; (c) December soil. Data are the mean \pm SE of 3 replicates. Full generic affiliations are given in Fig. (2). 
Table 2. Summary of Results from the Stepwise Multiple Regression Analysis, Separating Species into Categories Selected According to Significant Factors of (a) Time and (b) pH. Final Equations are Presented and the Significance of Individual Variables is Denoted as * $\boldsymbol{p}<0.05, * * p<0.01, * * * p<0.001$

\begin{tabular}{|c|c|c|c|c|c|c|}
\hline & Species & $r^{2}$ & $F$-Ratio & Significant Variables Selected & Parameter & $t$-Ratio \\
\hline \multirow[t]{3}{*}{ (a) Time } & Celosia argentea & 0.683 & $14.994 * *$ & $\begin{array}{c}\mathrm{b}_{0} \\
\text { time }\end{array}$ & $\begin{array}{r}58.800 \\
0.826\end{array}$ & $\begin{array}{r}8.569 * * * \\
3.872 * *\end{array}$ \\
\hline & Thunbergia erecta & 0.450 & $5.716^{*}$ & $\begin{array}{c}\mathrm{b}_{0} \\
\text { time }\end{array}$ & $\begin{array}{r}87.967 \\
0.670\end{array}$ & $\begin{array}{r}31.574 * * * \\
2.391 *\end{array}$ \\
\hline & $\begin{array}{l}\text { Zephyranthes } \\
\text { candida }\end{array}$ & 0.801 & $28.131 * * *$ & $\begin{array}{c}\mathrm{b}_{0} \\
\text { time }\end{array}$ & $\begin{array}{r}93.022 \\
0.895\end{array}$ & $\begin{array}{r}91.969 * * * \\
5.304 * * *\end{array}$ \\
\hline (b) $\mathrm{pH}$ & $\begin{array}{l}\text { Hibiscus rosa- } \\
\quad \text { sinensis }\end{array}$ & 0.515 & $7.442 *$ & $\begin{array}{c}\mathrm{b}_{0} \\
\mathrm{pH}\end{array}$ & $\begin{array}{r}108.137 \\
-0.718\end{array}$ & $\begin{array}{r}7.538^{* * * *} \\
-2.728^{*}\end{array}$ \\
\hline
\end{tabular}

only 4 pollen species, Celosia argentea, Nelumbo nucifera, Hibiscus rosa-sinensis, and Merremia umbellata, would be seen in the comparator samples.

Such data could be interpreted as showing no relationship between the different pollen assemblages. However, this study on pollen deterioration provides some explanation that forensic palynologists can use to explain why assemblages believed to come from the same site are different. Furthermore, loss of some pollen species provides important evidence since the missing pollen may provide a time interval marker between the collection of comparator samples and the time of the criminal action, when the perpetrator collected and removed pollen from the scene. However, before such evidence can be presented in court site specific experiments must be undertaken to provide the courts with the standard of forensic evidence required for the data to be acceptable.

Although, in this study, pollen was classified according to its ability to be identified, various states of pollen preservation were also obtained. These different states could also provide significant evidence since at a particular scene some pollen may be in a unique preservation state. For example, the preservation state of Coprosma, a common New Zealand pollen type, indicated a specific crime scene [41].

\section{CONCLUSION}

Pollen deterioration is a very complex process. Pollen preservation is a result of a combination of the properties of pollen grains themselves and their depositional circumstances. While the results of this present study were based on a small number of samples and counts it does show that great care must be taken when confronted with even short time intervals between the collection of comparator samples from a crime scene and the subsequent evidential samples collected from items taken away from that scene at the time the crime was committed. However, this study has illustrated distinctive trends that should lead towards more research into this aspect of palynology and its important contribution to all branches of palynology.

\section{ACKNOWLEDGEMENTS}

I would like to express my gratitude to Professor Dr. Bryant Vaughn, Texas A\&M University, USA, Dr. Anchana
Prathep, Dr. Brian Hodgson, Prince of Songkla University, Thailand, for suggestions that contributed greatly to this project. Financial support from the Graduate School, Prince of Songkla University, Thailand, a research grant and coadvisor grant, made this project possible. I gratefully acknowledge the Faculty of Science, Prince of Songkla University, Thailand for a research assistant grant and for financially supporting a visit to the Department of Ultrastructure Research and Palynology, University of Vienna, Vienna, Austria for developing the manuscript.

\section{REFERENCES}

[1] Erdtman, G. Handbook of palynology: An introduction to the study of pollen and spores. Hafner Publishing Co.: New York, 1969.

[2] Bryant, V.M.; Mildenhall, D.C. Forensic palynology: A new way to catch crooks. In New developments in palynomorph sampling, extraction, and analysis; Bryant, V.M.; Wrenn, J.W. Eds.; American Association of Stratigraphic Palynologists Contributions Series: 1998; 33, pp. 145-155.

[3] Bryant, V.M.; Mildenhall, D.C.; Jones, J.G. Forensic palynology in the United States of America. Palynology, 1990, 14, 193-208.

[4] Bryant, V.M. Pollen analysis of archaeological sediments from CA-SD1-13978 and CA-SD1-4420: MCB camp Joseph H. Pendleton, California. Final report prepared for RECON in San Diego, California; Palynology Laboratory, Texas A\&M University: Texas, 2005.

[5] Havinga, A.J. Investigation into the differential corrosion susceptibility of pollen and spores. Pollen Spores, 1964, 6, 621635.

[6] Havinga, A.J. A 20-year experimental investigation into the differential corrosion susceptibility of pollen and spores in various soil types. Pollen Spores, 1984, 26, 541-558.

[7] Cushing, E.J. Evidence for differential pollen preservation in late Quaternary sediments in Minnesota. Rev. Paleobot. Palynol., 1967, 4, 87-101.

[8] Hall, S.A. Deteriorated pollen grains and the interpretation of Quaternary pollen diagrams. Rev. Paleobot. Palynol., 1981, 32, 193-206.

[9] Bryant, V.M.; Hall, S.A. Archaeological palynology in the United States: A critique. Am. Antiquity, 1993, 58, 277-286.

[10] Bryant, V.M.; Holloway, R.; Jones, J.; Carlson, D. Pollen preservation in alkaline soils of the American Southwest. In Sedimentation of organic particles. Traverse, A. Ed.; Cambridge University Press: London, 1994, pp. 47-58.

[11] Campbell, I.D.; Campbell, C. Pollen preservation: Experimental wet-dry cycles in saline and desalinated sediments. Palynology, 1994, 18, 5-10.

[12] Havinga, A.J. Palynology and pollen preservation. Rev. Paleobot. Palynol., 1967, 2, 81-98.

[13] Birks, H.J.B. British trees and insects: A test of the time hypothesis over the last 13,000 years. Am. Nat., 1980, 115, 600-605.

[14] Milne, L.; Bryant, V.M.; Mildenhall, D.C. Forensic palynology. In Forensic botany: Principles and applications to criminal casework. 
Coyle, H.M. Ed.; CRC Press: Boca Raton, London, 2005, pp. 217252.

[15] Xinmiao, L.; Hui, C.; Qinghai, X. Surface pollen and its relationship to vegetation on the southern slope of the eastern Qilian Mountains. J. Geogr. Sci., 2006, 16, 215-222.

[16] Goldstein, S. Destruction of pollen by phycomycetes. Ecology, 1960, 41, 543-545.

[17] Holloway, R.G. Experimental mechanical pollen degradation and its application to Quaternary age deposits. Tex. J. Sci., 1989, 41, 131-145.

[18] Dimbleby, G.W. Pollen analysis of terrestrial soils. New Phytol., 1957, 56, 12-28.

[19] Tschudy, R.H. Relationship of palynomorphs to sedimentation. In Aspects of Palynology. Tschudy, R.; Scott, R. Eds.; Wiley \& Sons: New York, 1969.

[20] Campbell, I.D. Experimental mechanical destruction of pollen grains. Palynology, 1991, 15, 29-33.

[21] Huang, T.C. Pollen flora of Taiwan. National Taiwan University, Botany Department Press: Taipei, 1972.

[22] Telleria, M.C.; Daners, G. Pollen types in Southern New World Convolvulaceae and their taxonomic significance. Plant Syst. Evol., 2003, 243, 99-118.

[23] El Naggar, S.M. Pollen morphology of Egyptian Malvaceae: An assessment of taxonomic value. Turk. J. Bot., 2004, 28, 227-240.

[24] Rayment, G.E.; Higginson, F.R. Australian laboratory handbook of soil and water chemical methods. Inkata Press: Sydney, 1992.

[25] Montagnini, F.; Jordan, C.F. Tropical forest ecology: The basis for conservation and management (Tropical forestry). Springer: Berlin, Heidelberg, 2005.

[26] Racke, K.D.; Skidmore, M.W.; Hamilton, D.J.; Unsworth, J.B.; Miyamoto, J.; Cohen, S.Z. Pesticide fate in tropical soils (IUPAC report on pesticide). Pure Appl. Chem., 1997, 69, 1349-1371.

[27] Brooks, J.; Shaw, G. Chemical structure of the exine of pollen walls and a new function for carotenoids in nature. Nature, $\mathbf{1 9 6 8}$, $219,523-524$
[28] Shaw, G. The chemistry of sporopollenin. In Sporopollenin. Brooks, J.; Grant, P.; Muir, M.; Gijzel, P.V; Shaw, G. Eds.; Academic Press: New York, 1971, pp. 305-350.

[29] Rowley, J.R.; Prijanto, B. Selective destruction of the exine of pollen grains. Geophytology, 1977, 7, 1-23.

[30] Rowley, J.R. The fundamental structure of the pollen exine. In Morphology, development, and systematic relevance of pollen and spores. Hesse, M.; Ehrendorfer, F. Eds. Plant Syst. Evol. Suppl., 1990, 5, 13-29.

[31] Mildenhall, D.C. Fossil pollen of Acacia type from New Zealand. New Zealand J. Bot., 1972, 10, 485-494.

[32] Guinet, P.; Vassal, J.; Evans, C.S.; Maslin, B.R. Acacia (Mimosoideae): composition and affinities of the series Pulchellae Bentham. Bot. J. Linn. Soc., 1980, 80, 53-68.

[33] Chen, F.; Ciampolini, F.; Tiezzi, A.; Cresti, M. The ultrastructure of polymorphic pollen grains of Canna indica L. Sex Plant Reprod., 1989, 2, 193-198.

[34] Perveen, A.; Qaiser, M. Pollen Flora of Pakistan - XI. Leguminosae (Subfamily: Mimosoideae). Turk. J. Bot., 1998, 22, 151-156.

[35] Fortescue, J.A.; Turner, D.W. Pollen fertility in Musa: Viability in cultivars grown in Southern Australia. Aust. J. Agric. Res., 2004 55, 1085-1091

[36] Duhoux, E. Mechanism of exine rupture in hydrated taxoid type of pollen. Grana, 1982, 21, 1-7.

[37] Boulding, J.R. Practical handbook of soil, vadose zone and ground-water contamination: Assessment, prevention, and remediation; CRC Press: Boca Raton, Florida, 1995.

[38] White, R.E. Principles and Practice of Soil Science: The Soil as a Natural Resource. 3rd ed.; Blackwell Science Ltd: Carlton, 1997.

[39] Wiltshire, P.E.J. Consideration of some taphonomic variables of relevance to forensic palynological investigation in the United Kingdom. Forensic Sci. Int., 2006, 163, 173-182.

[40] Wiltshire, P.E.J. Hair as a source of forensic evidence in murder investigations. Forensic Sci. Int., 2006, 163, 241-248.

[41] Mildenhall, D.C. An unusual appearance of a common pollen type indicates the scene of the crime. Forensic Sci. Int., 2006, 163, 236240.

(c) Phuphumirat et al.; Licensee Bentham Open.

This is an open access article licensed under the terms of the Creative Commons Attribution Non-Commercial License (http://creativecommons.org/licenses/by-nc/3.0/) which permits unrestricted, non-commercial use, distribution and reproduction in any medium, provided the work is properly cited. 